DIGITAL COMMONS
@ UNIVERSITY OF SOUTH FLORIDA

Volume 10

Issue 2 Fall 2020

\section{ABO: Interactive Journal for Women in the Arts, 1640-1830}

\title{
A Travel Writer Reconsidered: Recovering Mary Morgan's Mary, the Osier-Peeler
}

\author{
Emily D. Spunaugle \\ Oakland University, spunaugle@oakland.edu
}

Follow this and additional works at: https://digitalcommons.usf.edu/abo

Part of the Feminist, Gender, and Sexuality Studies Commons, and the Literature in English, British Isles Commons

\section{Recommended Citation}

Spunaugle, Emily D. (2020) "A Travel Writer Reconsidered: Recovering Mary Morgan's Mary, the OsierPeeler," ABO: Interactive Journal for Women in the Arts, 1640-1830: Vol.10: Iss.2, Article 2. http://doi.org/10.5038/2157-7129.10.2.1218

Available at: https://digitalcommons.usf.edu/abo/vol10/iss2/2

This Scholarship is brought to you for free and open access by Digital Commons @ University of South Florida. It has been accepted for inclusion in ABO: Interactive Journal for Women in the Arts, 1640-1830 by an authorized administrator of Digital Commons @ University of South Florida. For more information, please contact digitalcommons@usf.edu. 


\title{
A Travel Writer Reconsidered: Recovering Mary Morgan's Mary, the Osier-Peeler
}

\author{
Abstract \\ Recently discovered is the singly-extant 1798 quarto chapbook, Mary, the Osier-Peeler, a Simple but True \\ Story, written by Mary Morgan, best known for her 1795 travel narrative, $A$ Tour to Milford Haven, in the \\ Year 1791. The inaccessibility of the osier poem has shaped the scholarly understanding of Morgan as \\ solely a travel writer, disregarding the intertextuality of her published oeuvre and its post-publication \\ circulation. This essay revisits the historiography of Mary Morgan and demonstrates her embeddedness \\ in local networks, coterie relationships with notables such as Bluestocking Elizabeth Montagu, and \\ introduces evidence of a broader, international audience to better contextualize Morgan's readership and \\ circulation. \\ Creative Commons License \\ (c) (1) (9) \\ This work is licensed under a Creative Commons Attribution-Noncommercial 4.0 License

\section{Cover Page Footnote} \\ The research for this essay was supported in part by travel grants from the Wayne State University (WSU) \\ Department of English and Oakland University (OU) Research Committee. Thanks go to Addenbrooke's \\ Hospital Archivist, Hilary Ritchie, and Acting Curator of the Wisbech and Fenlands Museum, Robert Bell. I \\ am grateful to Margie Friant of OU Libraries for her digital labor in creating images of the osier poem, and \\ many thanks otherwise to Lisa Maruca, Arthur Marotti, and Michael Scrivener of WSU, and Dominique \\ Daniel and Megan Peiser of OU.
}




\section{A Travel Writer Reconsidered: Recovering Mary Morgan's Mary, the Osier-Peeler}

Little can be more exciting to a literary historian than to recover a text lost for centuries - a manuscript, hiding within the binding of collected periodicals, or an unpublished diary sedimented in the county records office. But even among the fully catalogued items of a university library hide items whose literary, historical, and cultural value is obfuscated by the insufficiency of access points for addressing new research questions. Items authored anonymously or "by a lady" are particularly subject to oversight in knowledge structures dependent on known-author identification. An informal inventory of "by a lady" texts of the Special Collections of Oakland University's Kresge Library revealed such a discovery-a singly-extant 1798 petition poem purchased in 1971 as part of the Marguerite Hicks Collection to flesh out the holdings of the young university in Rochester, Michigan. A quarto chapbook interfiled among amatory fiction, collected letters, and conduct manuals, the lost Cambridgeshire pamphlet Mary, the Osier Peeler is exempt from the English Short Title Catalogue (ESTC), absent from Eighteenth Century Collections Online (ECCO), and, according to WorldCat, held only at Oakland University. ${ }^{1}$

The fourteen-page chapbook Mary the Osier-Peeler, A Simple but True Story was printed by John White in Wisbech in 1798 and authored anonymously, per the title page, "for the benefit of the distressed family described in it." The ballad follows the titular Mary, who supplements her meager earnings by joining the women of her community in the seasonal labor of peeling the bark of the osiers, or willows, grown along the riverbanks for the manufacture of hats, baskets, chairs, and more. In the celebrations following the completion of the work, Mary meets and falls in love with William, and the two marry. The balance of the poem catalogues the trajectory of their ever entrenching poverty and ever increasing family: Mary sustains postpartum blindness, and one of her children, unattended, is "night burnt to the bone" (171); William suffers from fevered illness and cannot afford rent, and they are evicted from their cottage to a "lodging most wretched" (205); the children contract measles and smallpox, leaving some of the osier children "freed from their mansions of clay" (214). At twelve years of age, the eldest son, also named William, is sent out to work to help support his family, but he suffers injury and is sent to the voluntary hospital in Cambridge. The poem ends with a lament upon the irrevocably injured young William's return to his family: "Lame and useless I fear I must be — / But alas! the chief cause of my grief / Is, in want my dear parents I see, / Unable to give them relief!" (317-20): this petition is poised as the final direct quotation from the lips of the family's representative supplicant.

For merely its engagement with the agrarian and cultural practices amid the tightening enclosure laws of late eighteenth-century Cambridgeshire, Mary the Osier-Peeler is more than a vanity publication. The osier poem's composition and publication is what Lisa Robertson, writing of Cambridge women poets - albeit in the twentieth and twenty-first centuries - considers "sitespecific," drawing on the accumulation of available referents particular to the built and natural environments of the city. ${ }^{2}$ Furthermore, archival research into Cambridgeshire repositories such as Addenbrooke's Hospital archives and the Wisbech and Fenland Museum reveal that the author of the osier poem is Mary Morgan, an author known to her contemporaries, though perhaps less so today, as a travel writer, author of A Tour to Milford Haven, in the Year 1791 
(1795) and The Knyghte of the Golden Locks (1799). Archival and bibliographical research into the text and production also support Morgan as the author of Mary, the Osier-Peeler.

In introducing this newly discovered text, this essay continues the directions for the recovery of women's writing articulated in the introduction to Jennie Batchelor and Gillian Dow's 2016 edited collection Women's Writing, 1660-1830: Feminisms and Futures, which identifies the lasting preference in literary studies for "certain models of authorship (the professional over the amateur) and certain genres (the novel and, to a somewhat lesser extent, poetry) above others in which women were both successful and skilled practitioners" (Batchelor and Dow 14-15). Work such as Batchelor and Dow's collection and that of others have long argued for the redefinition of success as criterion for consideration of women's writings, as the reconstruction of Morgan's authorship, readership, and coteried connectivity will reveal. This essay first revisits the historiography of 1790s travel writer Mary Morgan to contribute to our conception of her as author. Secondly, it introduces evidence of her embeddedness in coterie relationships that better contextualize her readership and circulation, ultimately gesturing to how other seemingly minor and provincial authors and readerships might be reconceptualized as active participants in various reading and writing communities. Finally, this essay introduces a newly recovered petition poem by Morgan for further visibility and fodder for inquiry.

\section{The mistaken identities of Mary Morgan}

Little is known about the personal life of Mary Morgan, born in 1749 to Mary and Joseph Gibbs, organist of St. Mary-le-Tower of Ipswich (Middleton). Her invisibility in the archive is punctuated by the professional milestones of her husband, Reverend Dr. Caesar Morgan (17501812), whom she married in 1776. Originally from Haverfordwest, Pembrokeshire, in Wales, Dr. Morgan was admitted as sizar to Christ's College Cambridge at age 18, ordained in 1774, and progressed through clerical assignments and further study until receiving his doctor in divinity in 1793 (ACAD). Reverend Morgan served as vicar of the parishes of Wisbech St. Peter and Wisbech St. Mary from 1795 until early 1802 (CCEd). The Morgans then moved to Ely, also in Cambridgeshire, for Dr. Morgan to assume Canon of Ely in 1804, and Mary Morgan died there in 1808. The two are buried and memorialized in Ely Cathedral, the seat of the Diocese of Ely.

As a writer, Mary Morgan is best known - if known at all - for her 1795 epistolary Welsh travel narrative, A Tour to Milford Haven, in the Year 1791 (TTMH), in which she accompanies her Welsh-born husband from Ely, Cambridgeshire, to Pembrokeshire, Wales. ${ }^{3}$ Morgan prefaces the sixty-two letters, holding that "many of these Letters stand verbatim as they were written, and many more with very little alteration," collected from eight distinct relatives and acquaintances and one household with whom she corresponded during her travels (viii). ${ }^{4}$ Morgan's Tour is often invoked for its description of famed Bluestocking Elizabeth Montagu's Sandleford Estate in Berkshire - specifically, Montagu's treatment of the laboring poor on the grounds. The Morgans, acquainted with Montagu's brother, the Rev. William Robinson, stopped at Robinson's Burghfield home and were invited to visit Sandleford, where Morgan observes of the laborers at Sandleford:

Upon enquiry I found they were all fed and cloathed by [Montagu's] hand. I perceived too that many of them had some great defect, occasioned by age, 
natural infirmity, or misfortune, being either blind, deaf, dumb, or lame; yet she had so paired them, and fitted their employments to their several faculties, that the remaining senses of one served to supply the deficiencies of the other. By this stroke of benevolent ingenuity, though she does not get so much work done, as she would by stronger and abler men; she has the heart-felt satisfaction of making those useful and happy members of society, whom nobody else would employ, and who, but for her, must be dependent upon a parish for an idle and scanty subsistence. I hope it is not prophane to say, she has made the blind to see, the deaf to hear, the dumb to speak, and the lame to walk. (39-40)

This moment has been often used to showcase Montagu's beneficence, or lack thereof, rather than for the perspective of its author, whose identity is often elided or confused. For example, Harriet Guest's Small Change excerpts the above passage to comment on the gendered, private virtue of Elizabeth Montagu but confuses Mary Morgan with a "Miss Morgan," the subject of a letter from Elizabeth Carter to Montagu who, according to Carter, "is likely to be ... advantageously established" (160); Mrs. Mary Morgan (née Gibbs) had been married since 1776. ${ }^{5}$ Similarly, Peter Denney instrumentalizes the Sandleford description of Morgan's tour to push back against prevalent readings of Montagu's benevolence to show Montagu "not so much dispensing charity as taking full advantage of cheap labor" (507). But Denney wrongly titles the author of the travel narrative Lady Morgan; this case of mistaken status contributes to Denney's reading of Morgan as complicit in the politicized aesthetic debates of the 1790s, which invariably impacted social relations. The erroneous title is also misleading to literary scholars of the long eighteenth century, for whom "Lady Morgan” signals Irish author Sydney Owenson.

Even when not misidentifying its author, readings of Tour to Milford Haven, in the Year 1791 relegate the text's status to a minor travel narrative and identify its author as solely a travel writer - characterizations that have forestalled further investigation into the function and circulation of the text, as well as the existence and interplay of other texts by Morgan. For example, Katie Garner identifies Morgan's Tour as the earliest Welsh travel narrative to draw heavily on Arthurian topoi. Garner lauds Morgan's engagement with Arthurian legend as the "earliest and most extensive expressions of interest in the Arthurian legend by a female writer," holding that the commitment of contemporaneous travelogues "pales somewhat in comparison" to Morgan's "lively narrator" (127). But it is worth pausing to note, in Garner's treatment of Morgan's Tour, the conspicuous absence of the "found manuscript" of The Knyghte of the Golden Locks, which would further buttress Garner's thesis: where, by Garner's calculation, Morgan devotes twenty-nine pages (roughly 6\%) of her Tour to engagement with Welsh folklore and Arthurian legend, Morgan also authors a text entirely concerned with these topoi.

The Knyghte of the Golden Locks claimed on its title page to be "selected from many others in the possession of Mrs. Morgan." The Knyghte, published in 1799 also by John White in Wisbech, takes up the Arthurian topos directly as "An Ancyent Poem," wherein Morgan positions herself as editor, supplying for the benefit of her readers modernized spelling and scholarly apparatus of explanatory footnotes to "explain a few of the most obsolete words" (6). Wise to her art, the Analytical Review admits that in The Knyghte, for her "motley orthography and diction, Mrs. M. has produced a tolerably good imitation" (526, my emphasis). Similar to her travel narrative, Morgan-as-editor leads a guided excursion, this time through feigned arcane 
orthography and footnoted allusion. Expanded attention to Morgan's oeuvre and the acknowledgement of her intertextuality would enliven readings of "Morgan's multigeneric travelogue" (Garner 134). Just as the text of Morgan's "ancyent poem" better contextualizes our knowledge of Morgan-as-travel-writer, so, too, can the recovery of her osier poem rejuvenate the existing historiography of Morgan. The cursory interrogation of the author of A Tour to Milford Haven in scholarly discourse, and the outright absence of Mary, the Osier-Peeler in major bibliographies and libraries, have limited understanding of its author. The inaccessibility of the osier poem has shaped Morgan exclusively into a travel writer, negating the intertextuality of her published oeuvre and its post-publication circulation.

\section{Establishing authorship of Mary, the Osier-Peeler}

The textblock of the single known copy of Mary, the Osier-Peeler bears the printed initials " $\mathrm{M}$. M." on the final page above the woodcut ornament with which Wisbech printer John White commonly closed his chapbooks. Using the enumerative bibliography of the English Short-Title Catalogue to investigate the output of Wisbech printers active during this era narrows the pool of possible authors: of the thirty-five known items printed by Wisbech stationers White and Nicholson, only one known author bears these initials. ${ }^{6}$ In 1798, the same year the osier poem appeared, White printed $A$ Sermon on Public Spirit, Preached at Wisbech, Isle of Ely by Morgan's husband, the Rev. Dr. Caesar Morgan; in 1799, White printed the aforementioned "found manuscript" of The Knyghte of the Golden Locks; White also served as the librarian to the Wisbech Literary Society — of which Dr. Morgan, too, was a member - as the minutes for the July 1797 meeting agree to "pay Mr. John White at the next annual meeting nine Guineas for a Room for the Reception of the Books and his Care as Librarian" (Minutes). The familiarity of the Morgans with White and the fact that he printed their work thus make plausible that the initials are those of Mary.

The berth of these publications harmonize with the geographic specificity of the Morgans' biographies. Rev. Morgan's assignment as vicar of the parishes of Wisbech St. Peter and Wisbech St. Mary from 1792 until early 1802 cements Mary Morgan's vocation as wife of a clergyman, situating her near the parish-supported poor. More compelling evidence corroborating "M. M." as Morgan's authorship arrives in the end of the text of the poem, wherein the twelve year-old son, farmed out to contribute to the family's income, "enfeebl' $d$ and fault-ring, at length / He droop'd, and could carry no more" (11. 287-88). Injured, the child is taken to Addenbrooke's Hospital in Cambridge, one of the first voluntary hospitals:

"To AdDEnBrooke's dome he was borne,

Where humanity waits at the gate,

To receive the diseas'd and forlorn,

And deep sighing bewails their hard fate." (11. 289-92)

Patients of Addenbrooke's were supported through the annual subscription fees of parish churches and landed gentry, averaging one guinea and two guineas per year $(£ 1,1 s$, and $2 £, 2 s)$. While the parishes of Wisbech St. Peter and St. Mary were not subscribers for the years surrounding the publication of the osier poem, the archives of Addenbrooke's Hospital indicate that a "Mrs. Morgan, of Wisbech" donated a lump sum benefaction of $£ 20$ in 1797 (State of 
Addenbrooke's Hospital). ${ }^{7}$ Of the 212 entities contributing to the income of Addenbrooke's Hospital for the year 1797, 190 were male individuals, 11 were cooperative or institutional subscribers (including parishes and groups of individuals), and only 11 were female individuals. The narrative of gendered and institutional charity is here disrupted by the unusual appearance of a woman, without title or substantial fortune, making a donation several times the amount of landed gentry. Here, the "site-specific" elements of Morgan's place of publication align with the stated intent and Morgan's documented charity project. This combination of geographic specificity of its provincial printing and the clerical assignment of her husband, the surviving printed output of John White, and the archival records Addenbrooke's Hospital uphold Mary Morgan as the poet. This conclusion is shared epitextually: while reviewed as an anonymous poem in Monthly Catalogue and Analytical Review, the Allgemeines Repertorium der Literatur drittes Quinquennium für die Jahre 1796 bis 1800 suggests, "Mrs. Morgan?" as author of the osier poem.

\section{Reconstructing local readership}

In reconsidering how "success" might be defined for Jane Cave Winscom and other writers working outside the London center, Norbert Schürer suggests scholars invest in aspects apart from canonization, including writers' contemporaneous "financial remuneration, local recognition, intellectual exploration and literary production" (416). This element of "local recognition" is particularly applicable to Mary Morgan, as what critics thus far have overlooked about Morgan was not occluded from her contemporaries. Morgan's participation in local writing and reading communities demonstrates not only that she fashions herself as author, but, importantly, that she is recognized as such by her contemporaries. Recognition in and embeddedness within provincial locales demands that the newly discovered osier poem be considered within this framework. Rather than dismissing this as upper-class vanity publishing, we should instead focus on the evidence of her author-function and her textual interfacing with fellow readers and writers.

To understand Morgan's role as a provincial writer recognized by her community, we must first understand her participation in the Wisbech Literary Society (WLS). The WLS was founded in 1781 by Quaker and Anglican businessmen and clergy on the rubble of the town library, which had struggled to thrive since its inception in the mid-seventeenth century. ${ }^{8}$ The Wisbech and Fenland Museum holds earlier catalogues of the town library and the minutes and accounts of the WLS; the minute books of the WLS, wherein members suggested books for purchase, start in 1797. The records reveal the reading interests of WLS and the literary aspirations of its membership and demonstrate the milieu in which Mary Morgan's lost osier poem was developed. Graham Best writes that, in earlier iterations of the town library, "[i]ntending to publish was rewarded of a loan of up to six books for four months - on the condition that a copy of the completed work be donated to the library when published," and that such an incentive would support "serious theological use" (330). Indeed, a review of the surviving printed output of the Wisbech printers John White and William Nicholson shows a sizeable number of Anglican and dissenter pamphlets and sermons. ${ }^{9}$ But this does not define the interests of the WLS, whose collecting interests favored the more sociable genre of travel literature over potentially divisive religious writings. Fortuitously, the accounts books begin in October 1794: assembled members agreed on April 11, 1795 to put money toward the subscription of A Tour to Milford Haven and 
noted in the accounts books, "By cash for Mrs. Morgan's Tour," paid in the amount of seven shillings, sixpence (Accounts). Apart from Morgan's travel narrative, the list of proposed book purchases from members spans histories, biographies, and a profusion of travel narratives, including Gray's Tour through Germany, Journal of an Excursion to America, and Stuart's Picturesque Tour through Part of Europe, Asia, and Africa. Requested books include even Matthew Lewis's scandalous novel The Monk, which is subsequently struck from the proposed list.

The interest of the WLS and its investment in Morgan's publication tesselate through the subscription list of TTMH and appear in other joint sponsorships of the text. Apart from the gentry, eminent clergymen, parliamentarians, and literary luminaries of the subscription list are six local literary societies: "Huntingdon Book Club, George Inn," "D* _ _ , Fountain Inn" (the set of dashes are likely ditto marks, denoting "Book Club"), "Literary Society, White Hart, Lincoln," "St. Ive's Book Club," "Somersham Book Club, Huntingdonshire," and the "Wisbeach [sic] Literary Society." That five other book clubs and/or literary societies supported the publication of TTMH shows a network of local reading clubs - all which likely also had their own mechanisms for admitting members, loaning books, and requesting new acquisitions. By the time the Morgans settled in Wisbech, the WLS was just shy of twenty-five official members and would grow to thirty-six by the end of the Morgans' tenure (WLS Catalogue 1815). Formal membership numbers cannot, however, capture the vast informal networks represented by the membership of the head of household - the possibility that one name represents an untold community of friends, relatives, women, children, and other inferiors that would have unprecedented access to a given book charged to an official member of a literary society. The copy of TTMH, yet held in the Wisbech and Fenland Museum, contains the penciled comments of several hands, indicating Morgan's readers commenting, editing, questioning, and otherwise interacting with her text. ${ }^{10}$

The Wisbech Literary Society provided a community for authors as well. Authorship and evidence of collaborative authorship is mediated through Mary Morgan's active role in the local literary scene as evidenced through the paratextual proof of her direct and indirect influence. A good example of this is a travel narrative, also printed by John White in 1798, entitled A Journal of a Tour to Scarborough, in the Summer of 1798. On the final page, the otherwise unidentified author signs his work as the "President of the Literary Society at W__," whom the records of the WLS identify as Mann Hutchesson (43). ${ }^{11}$ Hutchesson's pamphlet of forty-two pages not only registers as generic mimicry of Morgan but acknowledges her influence directly. Hutchesson peppers his travel narrative with quotations from establishment authors Horace, William Shenstone, Alexander Pope, and Samuel Johnson, cited in footnotes throughout his allusive text. Importantly, Hutchesson adds Mary Morgan to this authorial paratext just above White's finis ornament in a footnote: of the excerpt of Shenstone's "Written at an Inn at Henley," Hutchesson remarks, "A learned lady, Mrs. M. who honored me by reading my manuscript, has, in some poignant verses, combated this sentiment with her usual adroitness" (43). ${ }^{12}$ This footnote, apart from symbolically equating Morgan with the poetic genius of Horace, Pope, and Johnson in the mise-en-page, recognizes Morgan as a formative influence in the editorial revisions. Here, Hutchesson's remarks indicate Morgan's multiply valenced contributions: Morgan is critical editor and creative poet, indicating her pre-publication edits, here codified in printed acknowledgements, and writer herself, capable of "poignant verses." Furthermore, the 
"usual adroitness" that Hutchesson attributes to Morgan bespeaks a regularity of contact and intellectual exchange and suggests that Morgan's editorial labor is dispatched with regularity.

\section{Coterie relationships, informal reviews}

Beyond the confines of Wisbech, Cambridgeshire, and adjoining counties, Mary Morgan was also known through her correspondence, constituting another of the concentric circles in which she participated. The subscriber list of TTMH is "a handsome one," ostensibly consisting of the Morgans' friends, relatives, and acquaintances, details readers of A Tour to Milford Haven spread across England, spanning East Anglia to Wales (Monthly Review 274). Sarah Prescott writes that the "provincial subscription system based on supportive and sometimes charitable middling-rank social circles could be said to replace the role of the country house and library with its base in an older model of aristocratic literary production and patronal encouragement" (59). Importantly, these two valences of readership - acquaintance and printed circulationcoalesce in the two manuscript letters transcribed into a subscriber's copy of Morgan's A Tour to Milford Haven held by Cambridge University Library. ${ }^{13}$ The presence of such manuscript interventions offer another point of entry into Morgan's readership, not only illustrating a more intimate valence of use but also positioning Morgan within a coterie.

In articulating the relationship between scribal coteries and printed literary production, Betty Schellenberg has recently defined a coterie as a "select group of individuals linked by ties of friendship founded upon, or deepened by, mutual encouragement to original composition; the production and exchange of manuscript materials to celebrate the group and further its members' interests; and the criticism of one another's work and of shared reading materials" (2). In such a formation, a coterie expresses its connectivity not only through correspondence but as a "physically realized entity" that, despite fluctuation in membership over time, also requires "at least occasional geographical proximity" (9). Schellenberg uses as example the Bluestockings, whose correspondence on eighteenth-century respectability and moral teaching bears out one of the most famous examples of coterie connections. That the subscribers to TTMH include two Bluestockings-Frances Boscawen and "Bluestocking Queen" Elizabeth Montagu — not only places Morgan within a group of like-minded writers but links her to the exemplar of such formations in the final years of its existence. ${ }^{14}$ Furthermore, that the first transcription in the Cambridge copy of TTMH is from a letter from Montagu to Morgan, unknown to exist elsewhere, connects Morgan with this established group of women writers. These letters, transcribed into the flyleaves of the book, serve as informal reviews, indicating not only the interconnectivity of pride in the provincial with intimacy with celebrity but that the book's owner revisited the text to transcribe two letters, dating seven years apart. ${ }^{15}$ The distance between the publication of TTMH and the transcribed letters is bridged by the physical body of Mary Morgan who likely visited the Bullens to copy her epistolary reviews into the flyleaves.

Dated April 20, 1795, from Portman Square, Montagu's letter begins by highlighting the relationship between the two women and then moves to compliment the text itself:

I am happy to find I possess such a share of your friendship, as does me the highest honour. Your Pen gives such a beautifully animated description of all the objects you saw, that they want not the aid of the pencil. They were represented to 
the mind's eye with every perfection, and the moral observations and reflections, with which they are accompanied, render them as improving to the heart, as the other circumstances make them delightful to the imagination and taste.

As Montagu continues, however, she focuses more on the Morgans themselves: "As I have great obligation to Dr. Morgan and the truest respect for his character, I often reflect with great satisfaction, on his happiness in having such a Companion through the journey of life as Mrs. Morgan, who must make every stage of it agreeable, every circumstance pleasing." She then concludes by cementing their future friendship: "Oh my dear Madam! As the Muses are your fellow Travellers, make a Tour every Summer, and if you can condescend to make one individual happy, call every summer at Sandleford."

Montagu's "great obligation" and "truest respect" for Morgan's husband, her praise for Morgan herself, and her invitation for future visits all reveal the Morgans in far more intimate connection with Montagu than the mere tourists to Sandleford than the existing scholarship assumes. While Morgan is not an inner-circle Bluestocking, this transcribed excerpt positions Morgan as more than object of subscription patronage but rather as part of a textual dyad in which Morgan and Montagu each shore up the virtue and morality of the other-Morgan evincing admiration at Montagu's altruistic labor practices and Montagu supporting the literary endeavors of a youngergeneration writer, effecting, in this particular instance, a symbiotic relationship rendered visible in the public and private exchanges.

The second of the two letters transcribed in the Cambridge TTMH also highlights the geographic reach of Morgan's works. From watercolor artist Lady Gwillim (Elizabeth Symonds Gwillim) to Mary Morgan, it is dated February 10, 1802 and sent from British-held Madras.

I met with a Gentleman, who had bought the Welsh Tour in Bengal without knowing the Author, and enquired of me, if I had ever read it. He was highly delighted, when I told him, I had the honour to be acquainted with the Lady, who had written it. He was a Welsh man, and hearing me talk with pleasure of Wales, he recommended it to me as the best description of his native country and as a work much admired in Bengal, where it had been read by every body, and many copies sold.

Montagu and Lady Gwillim's Welsh acquaintance corroborate the verisimilitude of Morgan's account of Wales as exemplary. More importantly, Lady Gwillim's letter gives anecdotal evidence of the impact of Morgan's TTMH that exceeds the transnational book trade, in which the impression that TTMH was "read by every body" and "many copies sold" within the colonists' insular community evinces the power of the London trade in reaching the remote corners of its Empire. Just as Morgan's letterwriting served as sensemaking for her own microcosmic colonial foray into Wales, so does her published TTMH and Lady Gwillim's excerpted letter embody the geopolitical circuit of transglobal book market and its completion through the return of manuscript letters. Lady Gwillim's letter illustrates that even the remarkable subscription list of TTMH fails to articulate the impact and reach of Morgan. 


\section{Review rhetoric for the Welsh tour and burial of the osier poem}

Beyond the microtransactional evidence approximating the concrete exchanges between the Welsh tour and its individual readers, assaying the concept of Morgan's readership — writ large - depends on a genre of literature largely unappreciated by scholars studying the literary history of the eighteenth century, but through which so many readers of this period became acquainted with the era's literary productions: review periodicals. Morgan's work also appears in the literary reviewing organs, and thus achieves audiences beyond material access to the text of $T T M H$. But while literary reviews have long been assumed prescriptive dictators of taste formation - and this critical function cannot be altogether denied - recent scholarship shows that reviews expanded the horizons of readership by virtue of the excerpted portions being made available to its subscribers, and were read, annotated, and returned to on subsequent occasions. The easily excerptable, punchy dismissals of review rhetoric do not capture the nature of their use and circulation: for example, of Morgan's poetic modes in TTMH, the Monthly Review writes, "She never fails so much as when she attempts to write verses," and that "we cannot compliment her so far as to say that she appears to be a favourite with the muses" (274).

But excerpting only the seemingly condemnatory language of a review is misleading: an investigation into the practices of the reviewing organ and, most importantly, its use by readers, such as members of the WLS, demonstrates their variegated purposes. At the annual meeting of the Society in 1798, for example, it was determined that copies of the Monthly Review and British Critic "be stationary in the Library for a month and then be circulated as usual" to keep new issues of the periodicals readily available to readers. In the context of the WLS, the reviews were likely treated as "shopping lists" from which members could select and recommend new purchases at monthly meetings. Antonia Forster has demonstrated that, from the early days of the Monthly Review, its object was to allow readers to judge for themselves whether the reviewed book was worth its purchase by excerpting previews of the text, often to the point that "the giving of extracts may harm the sale of books" by revealing too much (180). The Novels Reviewed Database (NRD) leverages this feature of the genre and analyzes all reviews from the Critical Review and Monthly Review - the first two reviewing periodicals in England devoted exclusively to critically reviewing newly published works - to quantitatively identify conventions of length and treatment during 1790-1820, the period of literary history in which, for the first time, women authors outpublished men. Data from the NRD show that prose writing recognized as female in the Monthly Review in the 1790s garnered an average of 3 pages devoted to excerpted literary text and critical commentary: of these 3 pages, an average of 1.53 pages constitute the excerpted portion, and 1.47 the critical commentary (Peiser). That the Monthly Review allots five pages to its review of TTMF, and features 3.85 pages of excerpt substantive, verbatim excerpts of Morgan's text show that the TTMH review is atypical for women's prose writing of this period in a number of ways. The review devotes over twice the average real estate to directly quoting Morgan's text and less than the average critical commentary. Even compared to other female-authored travel-writing - a popular literary genre known for being heavilyexcerpted in reviews - that was reviewed by the Monthly Review in the same period (17901820), TTMF rises toward the top. Data collected by Women's Travel Writing, 1780-1840: A Bio-Bibliographical Database show that only half of published female-authored travel-writing was reviewed by the prestigious Monthly Review and less than one third by the equally-esteemed 
Critical Review. ${ }^{16}$ Of those thirty-three titles treated in nearly as many years by the Monthly Review, only eighteen meet or exceed the coverage given to Morgan, including the likes of Ann Radcliffe, the prolific fiction and travel-writer Elizabeth Isabella Spence, and Lady Sydney Morgan. ${ }^{17}$ The review of TTMH also appears in the coveted front section, rather than in the Monthly Catalogue. ${ }^{18}$ This data, paired with evidence of readers' use of review periodicals in the WLS and the generous excerpts in Morgan's own words included in the Monthly Review, would have reached readers beyond Morgan's spheres of influence, and its availability through Stockdale means it would have been available to bookbuyers through the London networks.

Until this point, this essay has focused on the under-examined readership of Mary Morgan's $T T M H$ through coterie relationships, local readership, her participation in local writing communities, and finally, (even) through review rhetoric. Against the backdrop of Morgan as successful writer, variously defined, we return at long last to the osier poem, published three years following the tour. The presence of only one known copy of the osier poem prevents, at present, inspection of multiple copies for marginalia, transcribed letters, and histories of ownership and use. The absence of a subscription list in this known copy forestalls investigation into possible coterie relationships or the osier poem's role in literary societies. The traces that $d o$ remain come from the reviews. Where the reviews' treatment of A Tour to Milford Haven, in the Year 1791 bespoke its importance to contemporaneous readers through the space devoted to the excerpted portion and preserved a way into the text for present-day scholars, Mary, the OsierPeeler is inversely damned. The same mechanisms at work in Mary, the Osier-Peeler govern the (im)possibilities inscribed by its materiality, printing berth, and contemporaneous reviews, thereby limiting our twenty-first century understanding of her reach and defining how the poem would be (dis)remembered.

Appearing in the Monthly Catalogue section, the review in the Critical Review exhibits a rare moment of compassion, affording half a page "not [to] criticise a poem published with so benevolent an intention," and excerpting three stanzas to "show its merit, and explain the nature of those distresses which the purchases will assist in relieving" (469). The Analytical Review devotes similar real estate to its review, reprints Morgan's prefatory advertisement describing Cambridgeshire, but dispenses with the previous periodical's generosity:

We really regret, that the lady, whose benevolence and sympathy prompted the exertion of her talents in behalf of an affectionate and very unfortunate family, should not have submitted her manuscript to the revision of some friend, because, we are persuaded, that the unmelodious lines, which now grate upon the ear, might have been corrected; and, from the simple touches of nature, which are here and there discoverable, we think her poem might easily have been rendered more worth of it's [sic] object, and better prepared for public perusal. (592)

It is precisely this imbalance between the review's extensive critical commentary and the excerpted portions of the poem that limits the readers' experience with Morgan's lines.

The berth of a text from London expands that text's availability — and thus its knowability —as London held the centralized, monopolistic structures built and policed by the Stationers Company that constitute the core/periphery dynamism of provincial publication. This effected 
the impenetrability of the London printing trade through its tight network, in which supply flowed downstream from predefined routes in London out to the provincial markets, also anchoring capital and profits within the London center as well. ${ }^{19}$ That the place of publication is Wisbech, well outside the London center, predetermines the possibilities of circulation. While also sold by the Rivingtons in London, Nicholson in Cambridge, and Edwards in Ely, the publication originates within a system of distribution not designed to support the return circulation of provincial output into the larger London market. Furthermore, even should readers become acquainted and moved by the charitable purpose of the petition poem, supply would have been unlikely to meet even minimal demand, as the limited print run of a petition poem would be considered mere jobwork, likely producing fewer than one hundred copies: the planned obsolescence of the osier poem written into its materiality.

Like so many other female authors, then, Morgan is here consigned to the double-edged forces of review rhetoric, which both enables exposure to Morgan's poetry to readers in digested form and enables the poem's dismissal via the mechanisms of canonization and eventually, the construction of literary history. At the end of her life, Morgan is acknowledged in her obituaries in the Gentleman's Magazine and The Athenaeum for her "vigorous understanding, a brilliant genius, an elegant taste, and a lively wit" ("Domestic Occurrences" 361). Most notable of these posthumous characterizations is that Morgan is recognized as "author of 'A Tour to Milford Haven, in 1791" - an intentional posturing of Morgan-as-author that stakes an important authorial claim to her best-known work, dismissing, with finality, the possibility of other texts. The reviews' patent linguistic and spatial dismissal of the osier poem further ensured its burial and led to limited understanding of her memorialization at the site of her literal burial in Ely Cathedral.

\section{Recovering the osier}

For a text so patently disregarded for over two hundred years, and which could never have attained the impact, however defined, registered by the Welsh tour, what, exactly, does the recovery of the osier poem recover? As an arguably internationally recognized author, Morgan intentionally chooses not to advance authorship or even leverage this relative success of her previously published book as imprimatur for the osier poem. Even so, the printed initials that the textblock bears indicate an intention to obfuscate - but not outright deny-her own authorship. How do we interpret provincial authorship that intentionally works against well-defined practices of leveraging previous success through authorial formations such as "by the author of" and others available in the period?

Identifying authorship of the osier poem invites intertextual invocation and interpretation across her texts. For starters, the osier poem engages in the generic conventions of travel writing in her description of the Fens: born in Ipswich, Morgan is herself an outsider and actively facilitates entrée into the Fenlands. The situatedness of the osier poem deploys the travel narrative "mode, similar to $T T M H$, to describe Cambridgeshire customs and industry to outsiders through a prefatorial author's note that explains the nature of osier-peeling:

It may be requisite to explain to those, who are not acquainted with the produce of Cambridgeshire, and the manners of the people, that rearing Osiers for making 
baskets, hats, \&c. is a profitable branch of trade, and peeling them for use, a favorite employment of the young women at a certain time of the year. When they have completed their work, they go in processions, dressed in their holyday clothes, decorated with the strips peeled from the rods; they collect contributions, and with them make a feast and a dance. The delicate Willow Hats, of late so fashionable, are made of Cambridgeshire Osiers.

The rationale of explaining to those "who are not acquainted with the produce of Cambridgeshire, and the manners of the people," for while osier-rearing and peeling would likely be known to readers in Wisbech, Cambridge, and Ely, potential readers in the fourth city of sale, London, would likely need explication of this region-specific practice. This travel mode of the osier poem also bridges Morgan's Welsh experiences in setting the scene in the first four stanzas of the poem, allowing her to recognize and leverage the lexical similarity that enables poetic slippage of the River Cam with "Cambrian shepherds," indicating or pertaining to Wales (MOP 17). Morgan furthers this duplicitous geospecificity when she admonishes the shepherds to "prepare ye the yew" (17), conjuring this and other churchyard imagery from Thomas Gray's and William Mason's Welsh elegies, but simultaneously invokes Milton's Lycidas, placing her textual Mary alongside “Cam's sedgy vale” (267). Morgan's poem also dissolves and repurposes review rhetoric to explain her invocation of Welsh shepherds gathering "Round his grave, while these tokens you strew" (19), sending her readers to a footnote to "[s] ee Mason's beautiful Poem on the custom in South Wales of strewing the graves with flowers" (6)-language with strong affinities to that in the Monthly Review, which similarly explains William Mason's poem "Elegy Written in a Church-Yard in South Wales" as largely "on the custom in that country of planting sweet herbs and flowers on the grave of a relation" (439).

Morgan ultimately leaves Mason, Gray, and Milton to their "sublime incantations" (34) along the riverbanks while the speaker ducks into the "willow-built cot to explore" (36)-shifting focus from the pastoral elegiac to a proto-social realism to visit the denizens "[w]ho by all are unknown and unseen" (39). "Where can music and harmony be," asks Morgan's speaker of the cottage inhabitants, "When pining with hunger and cold, / Eight children encircle the knee?" (4648). The balance of the forty-eight stanzas describes the osier family's struggles to negotiate the shifting rural makeshift economy in the wake of stringent enclosure laws. Her intensive focus on rural poverty requires that we reassess the sources and goals of her coterie authorship. For example, what new relationships might we conceive between Elizabeth Montagu and Mary Morgan, given the evidence of exchange between the two women and their mutual interest in good works? How might the osier poem further support and extend Zoë Kinsley's assertion that Morgan's Tour "emphasiz[es] the semblance between the charitable projects of [Sarah] Scott's ideal community at Millenium Hall and Montagu's estate at Sandleford" ("Mary Morgan's Tour" 222)? How might the osier poem extend Linda J. Van Netten Blimke's comparison of Morgan's descriptions of Sandleford and Blenheim to tease out Morgan's subtle political commentary? ${ }^{20}$ How formative was the Montagu we encounter in TTMH for Morgan in establishing her own charitable project through Addenbrooke's? As this essay has demonstrated, Morgan's role as author and editor within the Wisbech Literary Society, her engagement with review rhetoric in fashioning her own compositions, her acquaintance and correspondence with famed authors and distant colonists, and her literary and significant financial investment in a charitable project position Morgan at the nexus of complex and intertwined communities of reading and writing. 
Recovering the role played by this newly recovered text helps us reassess the goals of other provincial women's writing and the similar relationships that supported their work. Thus, it is important that it is republished to encourage new scholarship on the complex entailments of Mary Morgan's writings.

To date, the material scarcity of Mary, the Osier-Peeler has been reinscribed through its unavailability in digital collections such as Google Books and ECCO. Out of public circulation for two hundred years, Mary the Osier-Peeler complicates its own history of circulation in provincial coterie and extended metropolitan networks by now debuting in the open-access $A B O$. Like the poem's original publication, open-access publishing challenges traditional methods, circumventing the processes through which literary value and canonization impact collecting priorities in both the physical holdings and digital repositories of bibliographies, libraries, and other cultural institutions. The broader availability of texts like Mary, the Osier-Peeler, heretofore dismissed, invites scholars of all stripes - those within and without tenure-track lines, undergraduate and graduate students, independent scholars - to participate in important and ongoing recovery work, filling in information about writers like Mary Morgan and asking new questions that were previously inarticulable.

\section{NOTES}

${ }^{1}$ See OCLC accession number 15432739.

${ }^{2}$ See Gardner.

${ }^{3}$ Hereafter cited as TTMF. See Van Netten Blimke; Kinsley, "Beside the Seaside," "Travel and Material Culture," "Considering the Manuscript Travelogue," Women Writing the Home Tour, and "Mary Morgan's Tour."

${ }^{4}$ Correspondents include "Miss B.," "Mrs. B.," "Mr. B.," "Miss C.," "Mrs. G.," "Miss M.," "Mrs. M.," "Mrs. G.," and one letter addressed to "Miss R., Miss M. R., and Miss J. B."

${ }^{5}$ See Guest, 97-100.

${ }^{6}$ Titles returned by ESTC of texts printed in Wisbech in the years 1700-1800.

7 "Persons may recommend one In-Patient and two Out-Patients for every Guinea annually subscribed, and every Ten Guineas given in Benefactions" (Addenbrooke's 19).

${ }^{8}$ For more on the Wisbech Literary Society and its precursors, see Graham Best's "Libraries in the Parish," especially 328-30. See also Hanchant and Best, Books and Readers.

${ }^{9}$ An examination of the output of Wisbech printers listed in the English Short Title Catalogue reveals nearly one third are texts of a religious nature and constitutes the most numerous genre. ${ }^{10}$ The copy held by the Wisbech and Fenland Museum is also noted in The Catalogue of the Library of the Wisbech Museum.

${ }^{11}$ Per the WLS minutes, the president was Mann Hutchesson, town bailiff of Wisbech in 1788, member of the Society of Antiquaries of London, and the author of An Introduction to the Charter of Wisbech.

12 The Catalogue of the Library of the Wisbech Museum confirms that Hutchesson is the author (99). The meeting minutes of the Wisbech Literary Society for June 1798 also note that "The President was at Scarborough and not any member attended [the meeting]."

${ }^{13}$ The name "T. H. Bullen" or "J. H. Bullen" appears on the title page of the copy held in Cambridge University Library, Rare Books Room, shelflist Ll.34.13. 
14 The subscription list reads "Boscawen, Francis, esq. No 14, South Audley Street," which would seem to suggest a male, knighted relative of Mrs. Frances Evelyn-Glanville of Bluestocking fame. However, not only is such a "Francis Boscawen" absent from Debrett's Peerage, Burke's Peerage, and The Complete Peerage, Mrs. "Fanny" Boscawen was the occupant of Number 14 from her husband's death in 1764 until her own death in 1805 (Sheppard).

15 The same two letters also appear in Princeton University's copy, copied by the same hand, but with the hallmarks of a hurried writer. See Princeton University Library, Rare Books and Special Collections, call number 14887.643.652.

${ }^{16}$ Colbert identifies first-person accounts of travel "narratives, guidebooks, illustrated letterpress plate books, topographical descriptions, and collections" published in Britain and Ireland between 1780 and 1840. My inferences are drawn from the sixty-six female-authored travelwritings identified by Colbert published between 1790-1820 to compare with data drawn from the Novels Reviewed Database.

${ }^{17}$ Some of those titles include Ann Radcliffe's A Journey Made in the Summer of 1794 (1795); Elizabeth Isabella Spence's Sketches of the Present Manners, Customs, and Scenery of Scotland (1811); and Sydney Morgan's France (1817).

${ }^{18}$ For more on the relationship between importance and placement in the review periodicals, see Peiser.

${ }^{19}$ For more on the provincial book trade, see Feather.

${ }^{20}$ See Van Netten Blimke. 


\section{Works Cited}

The Accounts of Wisbech Literary Society, from 1794-1820. Box TL 25. Wisbech and Fenland Museum, Wisbech, Cambs. 11 July 2018.

Allgemeines Repertorium der Literatur drittes Quinquennium für die Jahre 1796 bis 1800. Verlage des Landes-Industrie-Comptoirs, 1807, sec. xiv, art. 3043. HathiTrust, https://hdl.handle.net/2027/ien.35556017203928?urlappend=\%3Bseq=1092. Accessed 25 Nov. 2017.

Batchelor, Jennie, and Gillian Dow. Introduction. Women's Writing, 1660-1830: Feminisms and Futures, edited by Jennie Batchelor and Gillian Dow, Springer, 2016, pp. 11-20.

Best, Graham. Books and Readers in Certain Eighteenth-Century Parish Libraries. 1985. Loughborough University, $\mathrm{PhD}$ dissertation.

—. "Libraries in the Parish." The Cambridge History of Libraries in Britain and Ireland: Provincial and Metropolitan Libraries, Volume II: 1640-1850, edited by Giles Mandelbrote and K. A. Manley, Cambridge UP, 2006, pp. 324-44.

The Catalogue of the Library of the Wisbech Museum: Comprising the Books Formerly Belonging to the Wisbech Literary Society, and Those of the Townshend Bequest. Cambridge UP, 2011.

"Caesar Morgan (unique identifier MRGN768C)." ACAD: A Cambridge Alumni Database, venn.lib.cam.ac.uk. Accessed 25 Nov. 2017.

"Caesar Morgan (CCEd Person ID 17964)." CCEd: The Clergy of the Church of England Database 1540-1835, http://www.theclergydatabase.org.uk. Accessed 25 Nov. 2017.

Carter, Elizabeth. "Letter CCXXXV." Letter to Elizabeth Robinson Montagu. 17 December 1781." Letters from Mrs. Elizabeth Carter, to Mrs. Montagu, between the Years 1755 and 1800. Chiefly upon Literary and Moral Subjects. Volume 3, Rivington, 1817, p. 160.

Colbert, Benjamin. Women's Travel Writing, 1780-1840: A Bio-Bibliographical Database. University of Wolverhampton, 2014, www.wlv.ac.uk/btw. Accessed 17 Jan. 2020.

"Domestic Occurences-Cambridgeshire." The Athenaeum, vol. 4, Oct. 1808, pp. 361-62. HathiTrust, https://babel.hathitrust.org/cgi/pt?id=iau.31858029258690;view=1up;seq=377.

Denney, Peter. “'Unpleasant, tho' Arcadian Spots': Plebeian Poetry, Polite Culture, and the Sentimental Economy of the Landscape Park." Criticism, vol. 47, no. 4, 2005, pp. 493514.

Feather, John. The Provincial Book Trade in Eighteenth-Century England. Cambridge UP, 1985. 
Forster, Antonia. "Review Journals and the Reading Public." Books and Their Readers in Eighteenth-Century England: New Essays, edited by Isabel Rivers, Continuum, 2001, pp. 171-90.

Gardner, Calum. "Residence at C_ "Writing Cambridge, special issue of Contemporary Women's Writing, edited by Veronica Forrest-Thomson and Lisa Robertson, vol. 10, no. 1, 2016, pp. 67-84.

Garner, Katie. 'Next Steps: Recovering the Arthurian Past in Women's Travel and Topographical Writing." Romantic Women Writers and Arthurian Legend: The Quest for Knowledge, Palgrave, pp. 115-62.

Guest, Harriet. Small Change: Women, Learning, Patriotism, 1750-1810. U of Chicago P, 2000.

Hanchant, W. L. "The Wisbech Literary Society." The Wisbech Society: $32^{\text {nd }}$ Annual Report, Wisbech Society and Preservation Trust, 1971, pp. 6-8.

Hutchesson, Mann. An Introduction to the Charter of Wisbech. W. Nicholson, 1791. Eighteenth Century Collections Online, ESTC: T071783.

[-.] A Journal of a Tour to Scarborough, in the Summer of 1798. John White, 1798. Eighteenth Century Collections Online, ESTC: T110747.

Kinsley, Zoë. "Beside the Seaside: Mary Morgan's Tour to Milford Haven, in the Year 1791." Travel Writing and Tourism in Britain and Ireland, edited by Benjamin Colbert, Palgrave, 2012, pp. 31-49.

—. "Considering the Manuscript Travelogue: The Journals of Dorothy Richardson (1761-1801)." Prose Studies: History, Theory, Criticism, vol. 26, no. 3, 2003, pp. 414-31.

-. "Mary Morgan's Tour to Milford Haven and Sarah Scott's Millenium Hall: Representations of Female Charity and the Example of Elizabeth Montagu." Eighteenth-Century Women: Studies in Their Lives, Work, and Culture, vol. 3, edited by Linda Troost, AMS Press, 2003, pp. 199-224.

—. "Travel and Material Culture: Commodity, Currency, and Destabilised Meaning in Women's Home Tour Writing." Studies in Travel Writing, vol. 10, no. 2, 2006, pp. 101-22.

—. Women Writing the Home Tour, 1682-1812. Ashgate, 2008.

Middleton, L. M. “Gibbs, Joseph (1699-1788), organist and composer.” Oxford Dictionary of National Biography, 23 Sept. 2004, https://doi.org/10.1093/ref:odnb/10605.

Minutes Book of the Wisbech Literary Society, 1797-1805. Box TL 25. Wisbech and Fenland Museum, Wisbech, Cambs. 11 July 2018. 
Morgan, Mary. The Knyghte of the Golden Locks: An Ancyent Poem, Applicable to the Present Times. John White, 1799.

[-]. Mary, the Osier-Peeler: A Simple but True Story: A Poem. John White, 1798.

—. A Tour to Milford Haven, in the Year 1791. Stockdale, 1795.

Morgan, Sydney. France. Henry Colburn, Public Library, Conduit Street, Hanover Square, 1817.

Peiser, Megan L. Novels Reviewed Database, 1790-1820 (NRD). Unpublished database.

—. "Reviews as Database: Reading the Review Periodical in Eighteenth-Century England." The Papers of the Bibliographical Society of America, vol. 111, no. 4, 2017, pp. 491-511

Prescott, Sarah. "Place and Publication." The Cambridge Companion to Women's Writing in Britain, 1660-1789, edited by Catherine Ingrassia, Cambridge UP, 2015, pp. 55-69.

—. "Women Travellers in Wales: Hester Lynch Thrale Piozzi, Mary Morgan and Elizabeth Isabella Spence." Studies in Travel Writing, vol. 18, no. 2, 2014, pp. 107-21.

Radcliffe, Ann. A Journey Made in the Summer of 1794, through Holland and the Western Frontier of Germany, with a Return down the Rhine: to Which Are Added Observations during a Tour to the Lakes of Lancashire, Westmoreland, and Cumberland. G. G. and J. Robinson, Pater-noster-Row, 1795.

Review of Knyghte of the Golden Locks, by Mary Morgan. Analytical Review, vol. 1, art. 31, May 1799, pp. 525-26. HathiTrust, https://hdl.handle.net/2027/hvd.hxjg4z?urlappend=\%3Bseq=585. Accessed 25 Nov. 2017.

Review of Mary, the Osier-Peeler, by Mary Morgan. Analytical Review, vol. 28, art. 10, Dec. 1798, p. 592. HathiTrust, https://hdl.handle.net/2027/hvd.hxju9j?urlappend=\%3Bseq=644. Accessed 25 Nov. 2017.

Review of Mary, the Osier-Peeler. Critical Review: Monthly Catalogue, series 2, vol. 24, Dec. 1798, p. 469. HathiTrust, https://hdl.handle.net/2027/hvd.hxj9r5?urlappend=\%3Bseq=479. Accessed 25 Nov. 2017.

Review of Poems, by William Mason, Monthly Review, series 2, vol. 22, art. 13, Apr. 1797, pp. 437-40. HathiTrust, https://hdl.handle.net/2027/chi.79231344?urlappend=\%3Bseq=451. Accessed 25 Nov. 2017.

Review of A Tour to Milford Haven, in the Year 1791, by Mary Morgan. Monthly Review, series 2, vol. 18, art. 8, Nov. 1795, pp. 269-74. HathiTrust, 
https://hdl.handle.net/2027/inu.30000093233157?urlappend=\%3Bseq=27. Accessed 25 Nov. 2017.

Schellenberg, Betty. Literary Coteries and the Making of Modern Print Culture, 17401790. Cambridge UP, 2016.

Schürer, Norbert. "Jane Cave Winscom: Provincial Poetry and the Metropolitan Connection." Journal for Eighteenth-Century Studies, vol. 36, no. 3, 2013, pp. 415-31.

Sheppard, F. H. W., editor. "South Audley Street: East Side." Survey of London: Volume 40, the Grosvenor Estate in Mayfair, Part 2 (The Buildings), London County Council, 1980, pp. 291-303. British History Online, http://www.british-history.ac.uk/surveylondon/vol40/pt2/pp291-303. Accessed 25 Nov. 2017.

Spence, Elizabeth Isabella. Sketches of the Present Manners, Customs, and Scenery of Scotland, with Incidental Remarks on the Scottish Character. Longman, Hurst, Rees, Orme, and Brown, Paternoster-Row, 1811.

The State of Addenbrooke's Hospital in the Town of Cambridge for the Year Ending Michaelmas $M D C C X V I$. Addenbrooke's Hospital Archives.

Van Netten Blimke, Linda J. "'The Tranquility of a Society of Females': Mary Morgan's A Tour to Milford Haven, Elizabeth Montagu, and the Transformative Politics of Female Governance." ABO: Interactive Journal for Women in the Arts, 1640-1830, vol. 9, no. 2, 2019. 